\title{
Comparative Analysis of Students' Attitudes Towards Migration in Russian Borderlands
}

\author{
RENALD SIMONYAN \\ MGIMO University under the Ministry of Foreign Affairs of the Russian Federation, 76, Prospect Vernadskogo, 119454, Moscow, Russia \\ Email: simonyan.renald@yandex.ru
}

\begin{abstract}
Migration studies are a major area of interest in social science. Globalisation and mediatisation hasten the advent of open societies where anyone can easily compare their aspirations in life with the lifestyles of people living in other states and, most importantly, neighbouring countries. Young people, who are more digitally confident and socioculturally mobile, have more opportunities to compare. Young specialists living in border regions are of particular interest because they live in a direct contact with neighbouring states. For the first time in social sciences, this article - which is a follow up to the contribution published in Issue 4 in 2020 - carries out a comparative analysis of the emigration attitudes of students from Russian regions bordering on the EU, Ukraine, Kazakhstan and China.
\end{abstract}

Keywords: cross-border regional studies, young specialists, attitude to emigration

\section{INTRODUCTION}

Coming to dominate public discourse, problems of migration require a thorough understanding. There is a growing need for surveys of the collective consciousness of social groups in labour exporting countries, of which Russia is one. Recent graduates of Russian universities make up a significant proportion of Russian emigrants. This situation is typical of all post-socialist European countries. The collective consciousness of Russia's younger generation is characterised by marked regional variations in the structure of motives and attitudes to emigration. The theory of mobility (Sorokin 2005) holds that spatial dynamics are turning into social capital benefitting its holder.

\section{FIVE CENTURIES OF RUSSIAN EMIGRATION}

Emigration from Russia has a long history dating back to the 16th century when many representatives of ancient boyar families - among whom was Prince Kurbsky, one of the most educated people of his time - emigrated to the Grand Duchy of Lithuania in fear of repressions. In the 7th-18th centuries, tens of thousands of Old Believers fled to the Grand Duchy after the Russian schism. In the 19th century, about $4 \mathrm{~m}$ people emigrated in search of employment. Most of them were landless serfs striving to reach America, which was in urgent need 
of labour. The 20th century added another four major emigration waves, the most massive of which was unleashed by the reforms of the 1990s.

Neither the general public nor academia have complete and reliable data on current Russian emigration. There is a wide divergence between Russian exit statistics and international entry data. This difference is explained by the Federal State Statistics Service (Rosstat) keeping only a partial emigration record.

Many Russian citizens are currently looking for a job abroad, doing this below the radar. They will enter foreign countries on work, business, tourist or visitor visas and contact their employers directly. None of them will appear in the statistics of the Federal Migration Service. Moreover, Russian authorities do not keep a record of Russians who have left the country to study or take a contract job and never returned.

This circumstance shows why emigration from Russia differs from Russian immigration into other countries. According to German statistics, the country welcomes five times as many Russian immigrants as Rosstat data suggest. Relevant information is available on the websites of Rosstat and the Federal Statistical Office of Germany (Statistisches Bundesamt).

According to Rosstat, about 5 m people left Russia in 1991-2016 to settle permanently in another country. A report prepared by Aleksey Kudrin's Civic Initiatives Committee, which was published on the organisation's website on 15 January 2017, estimates this number at 13-18 m people. ${ }^{1}$ This estimate seems more realistic because it corresponds to the data obtained by the director of the Russkiy Mir Foundation Vyacheslav Nikonov, who writes about $10 \mathrm{~m}$ Russians having emigrated to EU states by the beginning of 2009 (Nikonov 2009: 21).

Emigration from Russia, which began anew with the economic reforms of the 1990s, has been growing since then. The number of people considering emigration is increasing as well. Having gone through the brain drain of the 1990s, Russia is entering a new stage of rising emigration. Whilst 353,237 people left the country permanently in 2015, this number reached 440,831 people in 2018 according to Rosstat (Russia in Figures 2019: 82).

\section{YOUNG PEOPLE ARE THE MAIN COHORT OF EMIGRANTS}

Young adults, who are particularly susceptible to social change, make up most migration flows in today's world. The experience undergone at that age 'has overwhelming, shaping influence on all of their future lives' (Radaev 2018: 17).

The two last generations of Russian emigrants differ in many aspects. The emigrants of the 2000s, born in 1968-1981, belong to the 'generation of reforms'. They socialised at the time of immense social deprivation of late perestroika and the ensuing economic reforms of the 1990s. Those who emigrated in the 2010s were born in 1982-2000. They belong to the generation dubbed the 'millennials' , which was coming of age in the early 2000 s - a period of relative stability and prosperity in Russia. This generation has higher aspirations of life than the previous one.

The millennials are the most active group both socially and in terms of migration. The existential goals of the two generations differ as well. The generation of reforms, which socialised during perestroika against the backdrop of empty shelves at stores and a phenomenal crime, sought a comfortable way where they could grow old. The millennials seek job opportunities and brighter career prospects.

\footnotetext{
1 Komitet grazhdanskih iniciativ. Available at http://fb.com/KomitetGI

2 People born in 1981 and later, who reached young adulthood in the 21st century.
} 
According to a national survey conducted by the Levada Centre Polling Organisation on 23-28 May 2013, 45\% of Russian students aged 18 and over wanted to leave the country. ${ }^{3}$

Of course, pro-emigration attitudes do not mean imminent departure. To a large degree, they are just a dream of prosperity, which is inherent in humanity. There is a fair distance between a psychological attitude and action. Many barriers have to be overcome, including financial ones. It is assumed that only $4-5 \%$ of graduates willing to emigrate will actually do this (Kartashov 2007: 129). In 2020-2021, $4.1 \mathrm{~m}$ students study at Russian universities. If the data from the Levada Centre are to be believed (that is, that $45 \%$ of graduates consider leaving the country), Russia loses over 90,000 educated specialists each year. Some leading Russian universities have become exporters.

\section{THE SECOND STAGE OF THE STUDY OF REGIONAL CONSCIOUSNESS}

When analysing the problems of Russian emigration, it is necessary to consider the regional aspect. Russia is the largest country by area, and its regions are very diverse. The regional factor is the key to studying the causes of Russian emigration.

Perhaps the most interesting case is regions having a direct contact with neighbouring states, i.e. border regions. They provide an arena for actual cross-cultural interaction, and the problems of migration become both visible and operational there.

The first stage of the study was carried out in November 2018. It focused on a comparative analysis of Russian regions bordering on the EU and China. Its findings were published earlier in this journal.

The second stage of the study identified the factors that shape the pro-emigration attitudes of young specialists. My hypothesis was that university graduates willing to emigrate comprise a stable group that has significant distinguishing characteristics. Understanding the characteristics of this group could facilitate the creation of mechanisms to reduce the emigration rate. Another objective was to identify regional variations in the typological features, particularly as regards motives. This would help create locally targeted - and thus more effective - migration reduction mechanisms.

Border regions are dissimilar. Even the common characteristic of 'being subject to a border regime' is very different at the 'old' borders (with the EU and the CRP) and the new ones (with Ukraine and Kazakhstan). The border with the EU is tightly regulated, whilst the border regime between Russia and China is very relaxed. Established a long time ago, the 'old' borders have all the necessary infrastructure, whereas it is still under construction at the 'new' borders, which did not exist before the USSR disintegrated. While the 1,960 kmlong border with Ukraine is partly fenced, the 7,000 km-long border with Kazakhstan, on either side of which live both Russians and Kazakhs, has no barriers. Border barriers have been criticised as ineffective. Firstly, they require a massive expenditure. Secondly, locals who have friends and relations across the border will cut holes in the fencing. Thirdly, barriers compromise both cattle grazing and seasonal migration of wildlife. Fifthly, there is a communication problem. Seventeen railways and 226 motorways cross the Russian border. The average distance between its 48 checkpoints is $140-150 \mathrm{~km}$. These gaps make the border largely nominal.

All the four Russian borderlands have specific features, which naturally affect the mindsets of the residents.

\footnotetext{
3 Levada Centre. Press Release 06.06.2013.
} 
Eight hundred students were surveyed in June 2020 in Russia's western, southern and eastern border regions for a comparative analysis of attitudes towards emigration among the country's youth. Two hundred respondents were polled in the Kaliningrad, Belgorod, Orenburg and Khabarovsk regions, which border the EU, Ukraine, Kazakhstan and China, respectively.

The questionnaire surveys of final year students of the Immanuel Kant Baltic Federal University, Belgorod State University, Orenburg State University and Pacific State University were based on quota samples developed by the universities' sociological departments. The makeup of the sample reflected the departmental and specialisation makeup of students. The sampling error was $2.2 \%$ and the confidence level was $95 \%$. Developed by the author of the article, the data collection instruments were tested in $a$ series of emigration studies.

The four regions were chosen because of their engagement in cross-border cooperation, the proximity of the regional capital - and the university - to the border, and, most importantly, the comparative parity of incomes in the four territories.

Russia's enclave in the EU, Kaliningrad ranks 9th among the country's 85 regions in terms of household income. The city of Kaliningrad lies $37 \mathrm{~km}$ away from Poland and $60 \mathrm{~km}$ away from Lithuania. The Belgorod region is one of the most prosperous regions, with the 6th-highest household income in Russia. It closely cooperates with Ukraine, which is just $40 \mathrm{~km}$ away from the city. The distance between Belgorod and Kharkiv, Ukraine's second-largest city, is $68 \mathrm{~km}$. The Orenburg region stretches along the $1700 \mathrm{~km}$-long border with Kazakhstan, and active cross-border cooperation takes place throughout its length. Kazakhs account for 180,000 of the region's $1.4 \mathrm{~m}$ population. Most of them live in border districts. Orenburg borders on three regions of Kazakhstan - West Kazakhstan, Aktobe and Kostanay, which are home to 570,000 Russians. In the eastern Russian borderlands, the Khabarovsk region has the strongest economic ties with China. Its capital lies $19 \mathrm{~km}$ away from the Chinese border.

Asian Russia is much poorer than European Russia. Yet the Khabarovsk region, one of the most industrially developed territories in Russia's Far East, and the Orenburg region, a seat of the oil production and refining industry, rank 29th and 30th among the country's regions in terms of household income. Therefore, poverty can be eliminated as a principal motive for emigration. The study can be considered unbiased in this respect.

\section{PRO-EMIGRATION ATTITUDES AMONG STUDENTS IN RUSSIAN BORDERLANDS}

The study confirmed wide regional variations in the collective consciousness of students. It also helped identify the typological features of prospective young emigrants. Pro-emigration attitudes were shared by $58.8 \%$ of respondents: $64.7 \%$ in Kaliningrad, $59.6 \%$ in Belgorod, $48.0 \%$ in Orenburg and $62.9 \%$ in Khabarovsk. For convenience, respondents considering emigration will be referred to as emigrants.

Differences begin as soon as self-identification is concerned. Most respondents mentioned national identity: 46.0\% in Kaliningrad, 51.7\% in Belgorod, $48.0 \%$ in Belgorod and $62.7 \%$ in Khabarovsk (50.2\% on average). Ethnic identity was the second most frequently cited - mentioned by $29.4 \%$ in Kaliningrad, $24.2 \%$ in Belgorod, $37.2 \%$ in Orenburg and $20.1 \%$ in Khabarovsk (27.7\% on average). The third most cited identity was territorial, brought up by $24.5 \%$ of respondents in Kaliningrad, $24.1 \%$ in Belgorod, $14.8 \%$ in Orenburg and $17.0 \%$ in Khabarovsk (22.1\% on average). The proportion of emigrants was the smallest 
among those who emphasised national identity - 55.9\% in Kaliningrad, 55.4\% in Belgorod, $42.7 \%$ in Orenburg and $59.7 \%$ in Khabarovsk (53.6\% on average). The proportion of emigrants was much higher among those who cited ethnic identity $-64.1 \%$ on average (65.7, $69.5,51.4$ and $69.0 \%$, respectively). This result is in line with the global rise of nationalism. The trend is less pronounced in Orenburg (slightly over a half against two-thirds in the other regions).

Surprisingly, the highest proportion of emigrants - 65.9\% - was among those who link their identity to the region where they live $(78.3,63.2,57.9$ and $64.5 \%$, respectively). One might expect that devotion to one's birthplace, which trumps nationality and ethnicity, will preclude emigration since the latter does not fit in the traditional idea of love for one's country, of patriotism. The sense of space innate in a person of the globalization era is very different from that characteristic of people of previous ages. Patriotism today is not ideological but rational. Emigrants raise the prestige of their motherland by unlocking their creative potential. Undeniably, many emigrants have increased the profile of Russian culture and science. Among them were Alexander Herzen, Ilya Mechnikov, Ivan Bunin, Sergey Rakhmaninov, Igor Sikorksy, Yevgeny Zamyatin, Vladimir Nabokov, Vasily Kandinsky, Konstantin Korovin, Fedor Shalyapin, Pitirim Sorokin, Igor Stravinsky, Alexei Abrikosov, Ilya Prigogine, Rudolf Nureyev, Mikhail Baryshnikov, Aleksandr Solzhenitsyn, Andre Geim, Konstantin Novoselov, Joseph Brodsky. The list could go on.

Against the backdrop of increasing territorial movements, emigration is not always divorced from patriotism. Each individual strives to unlock their full potential and looks for the best conditions to do so. The financial situation, which may facilitate the achievement of the existential goal, is also taken into account.

The analysis of this factor is complicated by that people assess their financial standing against very different standards. As a rule, they compare their own situation with that in a neighbouring region or country. Russian western borderlands are more economically developed than their eastern counterparts. Yet young people living in the east consider themselves better off economically than their western peers. Comparing the Kaliningraders with the Lithuanians and the Poles in terms of standards of living does not reflect well on the Russians, whilst residents of the eastern borderlands look good when compared to the Chinese.

A central element of today's public discourse in Russia is the question as to which civilisation the country belongs to. European civilisation spans a diversity of ethnic cultures, Christian denominations and regional variations. For example, the Mediterranean lifestyle is very different from that lived in Scandinavia. Like other Europeans, the Russians have specific ethnocultural features. They are widely discussed in the context of a 'special Russian civilisation', which is implicitly opposed to European civilisation (Simonyan 2013).

Since the Russian-Ukraine crisis of 2014 and the imposition of sanctions, the theme of a 'special Russian' civilisation has been prominent in cultural studies discourse. Still, none of its advocates can differentiate between Russian and European values. Furthermore, the Constitution of Russia contains all the basic values and rules accepted in Europe. The idea of a 'Russian world' is conceptually akin to a 'Spanish world'. Spoken by over half a billion people, Spanish is the official language of 18 countries and a recognized national language in four states. The contribution of the Spaniards to European philosophy, literature, arts and music is comparable to that of the Russians. Similar reasons can be given in support of English, French 
or German worlds, all of which have unique national and denominational features. No matter how diverse European nations are, their common ground is European, or Christian, civilisation. Until the end of the 19 th century, Europe was called Christendom. ${ }^{4}$

In the past, peoples of the European rim - the Russians and the Spaniards - experienced invasion from belligerent neighbours. Spain was conquered by the Arabs and remained under their rule for 700 years. Rus' suffered under the yoke of the Golden Horde. Many Balkan nations shared a similar fate, having lived under Ottoman rule for the same 700 years. Influenced by the conquerors, these nations managed to preserve Christianity as their core system of values. Fedor Dostoevsky conceptualised this idea as follows: 'We Russians have two motherlands: our Rus, and Europe' (Dostoevsky 1985: 273).

Having borne the brunt of the military might of their neighbours, the peoples of the European borderlands protected the geographical centre of Europe - the core of European civilisation - from Muslim and Mongolian invasions. These nations, particularly the peoples of the eastern borderlands, paid a terrible price - they lagged behind the central European states of England, France and Germany in socio-economic development. 'National underperformance' caused many identity complexes.

Unlike the proponents of a 'special Russian civilisation', members of other nations view Russians as Europeans. Our survey results show that most respondents share this opinion. The feeling that they belong to European civilisation is stronger among emigrants. Whilst $54.5 \%$ of Kaliningrad respondents believe that Russia is part of European civilisation and $25.1 \%$ think that it is not, among emigrants, this ratio reaches 56.7:23.1\%. In Belgorod, these ratios are 49.7:20.2 and 51.5:19.0\%; in Orenburg, 50.5:27.3 and 53.0:17.3\%; in Khabarovsk, 48.7:20.1 and 52.6:18.8\%.

Most Russian emigrants head for Europe because of its geographic, cultural and historical proximity. Shared civilizational space is not the only thing that appeals to young Russians. There is yet another significant factor - Europe is the gold standard of a modern economic structure. Europe managed to create a social system that agrees with the very nature of human beings who seek personal success and freedom. In a market economy, this system ensures wealth as well as equal freedoms and opportunities for all (Simonian 2017: 320). For young people, equal opportunities mean tuition-free education and social mobility.

In the post-war period, a new socio-economic phenomenon - the welfare state - emerged in Europe. It is founded on the balance between the basic values of human society - freedom and justice. They dominate the value system of respondents who tend to choose liberal values (86.2\% of all respondents and $91.3 \%$ of emigrants) over statist ones ( 7.8 and $5.1 \%$, respectively).

The fact that most respondents see their country as European places greater demands on the machinery of government. The proportion of respondents saying that Russia is moving in the right direction was insignificant: 3.7\% in Kaliningrad, $4.3 \%$ in Belgorod, 5.5\% in Orenburg and $1.8 \%$ in Khabarovsk. Among emigrants, these figures are even lower: 3.0, 3.8, 2.8 and $0.5 \%$, respectively. The proportion of those who strongly disagree with the right direction' statement reached $43.2 \%$ in Kaliningrad, 35.7\% in Belgorod, 24.5\% in Orenburg and $45.8 \%$ in Khabarovsk. Among emigrants, these figures were 49.7, 47.3, 28.9 and 53.8\%, respectively. The average among all respondents was $37.4 \%$. Those who consider emigration were more critical of the current state of affairs ( $45.7 \%$ strongly disagreed with the statement).

4 For example, the German author Georg Philipp Friedrich Freiherr von Hardenberg, better known as Novalis, titled his programme essay of 1799 Christendom or Europe. 
Independence of opinion is explained by the fact that young Russians are less influenced by the official media, particularly state television channels. Students trust information found on the Internet (25.9\% in Kaliningrad, 36.5\% in Belgorod, $28.8 \%$ in Orenburg and $31.4 \%$ in Khabarovsk); acquired through personal experience (25.4\% in Kaliningrad, $16.8 \%$ in Belgorod, $13.8 \%$ in Orenburg and $19.7 \%$ in Khabarovsk); obtained from friends and acquaintances (19.7\% in Kaliningrad, $16.8 \%$ in Belgorod, $15.9 \%$ in Orenburg and $17.7 \%$ in Khabarovsk). Television is the fourth most popular source of information. It is used as such by $13.0 \%$ of respondents in Kaliningrad, $15.2 \%$ in Belgorod, $16.5 \%$ in Orenburg and 12.7\% in Khabarovsk. Still, as compared to radio, books, cinema, newspapers and magazines as sources of information, television is more popular by far. Most respondents had been to European countries and could compare media reports with their own observations.

The ideas and attitudes of the younger generation are a far cry from the official narrative. This difference is visible in the evaluation of negative scenarios - national security threats from within and without. In Kaliningrad, $18.7 \%$ of respondents were apprehensive of external threats (13.0\% among emigrants); in Belgorod, 19.3 and 10.7\%, respectively; in Orenburg, 38 and $25.4 \%$; in Khabarovsk, 17.9 and $15.3 \%$. Residents of the borderlands have a more accurate picture of attitudes dominant in adjacent countries and their neighbours' aggressive intentions. Respondents had much deeper concerns about internal threats. They were mentioned by $64.5 \%$ of respondents in Kaliningrad (68.3\% among emigrants); $53.7 \%$ (59.5) in Belgorod; $39.0 \%$ (49.7) in Orenburg; 64.2\% (71.5) in Khabarovsk.

Opinions about the sociopolitical situation in the country are also very different from the official narrative. Few respondents consider the state of affairs as favourable: $9.1 \%$ in Kaliningrad (6.3\% among emigrants); $9.8 \%$ (7.2) in Belgorod; $11.8 \%$ (5.1) in Orenburg; $4.2 \%$ (3.1) in Khabarovsk. Most respondents described the situation as tense, and there was no difference between all respondents and emigrants in this respect. On average, this opinion was cited by 56.1 and $55.8 \%$ of respondents, respectively. Many believe that the situation in the country is critical: $25.7 \%$ (31.7) in Kaliningrad; $25.8 \%$ (34.7) in Belgorod; $16.7 \%$ (20.8) in Orenburg; $33.4 \%$ (39.6) in Khabarovsk. ${ }^{5}$

These opinions lead to negative attitudes to politicians and politics. Most respondents distrust politicians: $39.7 \%$ in Kaliningrad (44.3\% among emigrants); 36.5 and $40.5 \%$, respectively in Belgorod; 29.5 and 31.7\% in Orenburg; 40.6 and $44.7 \%$ in Khabarovsk. A quarter of respondents said they were indifferent to politics and politicians. This opinion was shared by from 22.3 to $27.5 \%$ in Kaliningrad, Belgorod and Orenburg. In Khabarovsk, swept by protests at the time, this figure was much lower - 10.2 and $8.7 \%$, respectively. A quarter of respondents said they were concerned about politics: 24.8 and 25.1\% in Kaliningrad; 22.7 and 23.2\% in Belgorod; 18.0 and $27.1 \%$ in Orenburg. In Khabarovsk, this proportion was much higher -34.2 and $39.8 \%$, respectively.

One of the disciplines that the final-year students familiarised themselves with is social science. It defines functions of the state as those of a social system established for meeting the social, economic and cultural needs of citizens. Emigration is often a response to the failure of the state to fulfil these functions. As expected, the least satisfied needs were financial ones. They were mentioned by $57.6 \%$ of respondents in Kaliningrad $(56.2 \%$ among emigrants); $73.9 \%$ (77.2) in Belgorod; 77.2\% (59.6) in Orenburg; 66.1\% (57.2) in Khabarovsk.

5 Mass rallies began in Khabarovsk on 11 July 2020. In mid-June, when the polls were taken, the situation in the city was already explosive. 
These results confirm that material well-being is one of the strongest motives behind global emigration. Still, there is a considerable proportion of those who seek to fulfil their talents and potentials. The motive is very frequent among millennials. The inability to realise their potential was cited by $25.8 \%$ of respondents in Kaliningrad (29.7\% among emigrants); $19.1 \%$ (22.8) in Belgorod; $14.0 \%$ (23.7) in Orenburg; 22.4\% (27.5) in Khabarovsk.

\section{CONCLUSIONS}

This study of young residents of Russian border regions has shown that they have a rational approach to life, independent opinions and critical attitudes towards politicians and their actions. Students living in regions bordering the EU and China have a deeper insight into the situation in the country than their peers from regions bordering on CIS countries. In this respect, Belgorod and especially Orenburg come across as more conservative.

Final-year students who consider emigration outperform their peers on a range of regional consciousness measures. Students with pro-emigration attitudes feel more strongly about instances of bad governance. The attitudes of these young people are becoming a litmus test of current social processes. This socially useful quality should be employed in enhancing the system of public administration and solving the urgent problem of reducing the outflow of young specialists from Russia. 'Amid increasing globalization, there are no ways to replace human intellectual potential as a key resource of society' (Rimashevskaya 2003: 123).

In July 2014, the EU imposed economic sanction on Russia, which included financial restrictions on Russia's largest banks, a ban on exports of some goods and technologies, and lending restrictions. In the first months after the sanctions were announced, Russian citizens did not feel a decline in living standards.

On 14 August 2014, the Russian Public Opinion Research Center carried out a national poll whose results confirmed that the younger generation had pro-emigration attitudes. 'Most emigrants are young (73\%), educated (74\%), well-to-do (68\%) and come from major Russian cities (67\%). These people were described as active (79\%), strong (62\%), creative professionals (43\%). They are the elite reservoir of national talent.' ${ }^{6}$ This list of qualities of prospective young emigrants, which are perceived as the elite reservoir of national talent, should also include the characteristic 'independent thinkers' - a property key to the concept of a national elite.

This survey was the last pre-sanction study of emigration. Since 2015, the emigration rate has been rising. Preventing the best human resources of the nation from emigration requires improving youth policy. To this end, it is necessary to broaden the theoretical and empirical scope of studies in the field. It is essential to take account of regional variations. This research has demonstrated that even border regions, which are homogenous and similar in many aspects, have marked differences.

\section{ACKNOWLEDGEMENTS}

The article was prepared in the framework of a research grant funded by the Ministry of Science and Higher Education of the Russian Federation (Grant ID: 075-15-2020-930).

\footnotetext{
6 Russian Public Opinion Research Center 2014. Press Release No. 2902.
} 


\title{
Bibliography
}

1. Dostoevsky, F. 1985. Collected Works in 30 Volumes. Vol. 24. Leningrad.

2. Kartashov, G. 2007. 'Scale of Migration of Russian Students', Higher Education in Russia 11: 128-132.

3. Nikonov, V. 2009. 'Just Who Are the Russians?', Ethno-Dialogues Almanac 1: 12-23.

4. Radaev, V. 2018. 'How Millennials Differ from Previous Generations: An Empirical Analysis', Sociological Studies 3: 15-33.

5. Rimashevskaya, N. 2003. Man and Reforms: Survival Secrets. Moscow.

6. Russia in Figures. Statistical Handbook. 2018. Moscow.

7. Russia in Figures. Statistical Handbook. 2019. Moscow.

8. Simonyan, R. 2013. 'Is There a Special "Russian Way?"', Sociological Studies 7: 137-149.

9. Simonyan, R. 2017. 'Migration Attitudes of Russian Youth: A Regional Dimension', Monitoring of Public Opinion: Economic and Social Changes 6: 313-326.

10. Sorokin, P. 2005. Social Mobility. Moscow.

RENALDAS SIMONIANAS

\section{Rusijos paribio studentų migracinių nuostatu palyginamoji analizè}

\begin{abstract}
Santrauka
Migraciniai procesai yra vienas iš svarbiausių socialinių tyrimų objektų. Globalizacija ir medijų itaka skatina atvirosios visuomenès susidarymą, kurioje kiekvienas individas gali lyginti savo gyvenimo siekius su žmonių, gyvenančių kitose šalyse, ypač kaimyninèse valstybėse, gyvenimo būdu. Dideles lyginimo galimybes turi jaunimas, nes jis ypač paslankus tiek informaciniame lauke, tiek sociokultūrinèje erdvejje. Tyrèjų dèmesị traukia paribio regionų jauni specialistai. Šis straipsnis yra 2020 m. Nr. 4 Filosofijos. Sociologijos žurnale publikuoto straipsnio „Rusijos-Europos ir Rusijos-Kinijos paribio studentijos regioninès savimonès palyginamoji analizè tęsinys. Darbe analizuojamos Rusijos regionų, kurie ribojasi su Europos Sąungos šalimis, Ukraina, Kazachstanu ir Kinija, orientuotos ị emigraciją studentijos nuostatos.
\end{abstract}

Raktažodžiai: tarpvalstybiniai regioniniai tyrimai, jauni specialistai, nuostata migruoti 